\title{
Punishment in Negotiated Transitions: The Case of the Colombian Peace Agreement with the FARC-EP
}

\author{
Lily Rueda Guzman
}

Doctoral candidate, Department of Criminal Law and Criminology, Faculty of Law, vu University Amsterdam, Amsterdam, The Netherlands; Judge, Amnesty Chamber, Special Jurisdiction for Peace, Colombia

l.a.ruedaguzman@vu.nl

\section{Barbora Holá}

Senior Researcher, Netherlands Institute for the Study of Crime and Law Enforcement (NSCR); Associate Professor, Department of Criminal Law and Criminology, Faculty of Law, vu University Amsterdam, Amsterdam, The Netherlands

bhola@nscr.nl

\begin{abstract}
The peace agreement recently concluded between the Government of Colombia and the FARC-EP not only marked a milestone in the history of Colombia and peace making; it also introduced an unprecedented penal measure: negotiated criminal punishment. This example demonstrates that criminal punishment can be moulded to accommodate the needs of a society undergoing a political transition triggered by a peace negotiation. In the 1990 os Garland already pointed out that penal measures are shaped by their social and historical context, and also affect their social environment. Based mainly on a sociological perspective on punishment, this article analyses the relationship between the punishment negotiated in the recent peace talks with the FARC-EP and the Colombian government's trying to come to terms with atrocities committed during the armed conflict. Based on the Colombian experience, this article also outlines contextual factors, which shape how punishment is negotiated in the context of peace agreements
\end{abstract}

(C) LILY RUEDA GUZMAN AND BARBORA HOLÁ, 2018 | DOI 10.1163/15718123-01901006

This is an open access article distributed under the terms of the prevailing CC-BY-NC license at the time of publication. 


\section{Keywords}

Colombia - Fuerzas Armadas Revolucionarias de Colombia (FARC-EP) - political transition - punishment in transition - peace negotiation - sociology of punishment

\section{Introduction}

In November 2016 the Colombian government and the Fuerzas Armadas Revolucionarias de Colombia (FARC-EP), the main guerrilla group in the country, reached a historical peace agreement to end more than fifty years of war. ${ }^{1}$ The protracted internal armed conflict caused massive victimisation. Grave human rights violations and international crimes have been allegedly committed by all sides to the conflict. ${ }^{2}$ Up to October 2018 , there have been $8,760,290$ registered victims. ${ }^{3}$ The peace agreement, on the one hand, provides for the 'broadest amnesty possible'. On the other hand, those considered most responsible for the most serious crimes who cannot be legally amnestied, will benefit from restorative sanctions that do not entail incarceration, but consist of reparations and community service in war-torn regions of the country. This penal policy was designed as part of a broader 'Comprehensive system to satisfy victims' rights to truth, justice, reparation and non-repetition', which includes not only a Special Jurisdiction for Peace (sJP) in charge of prosecuting, judging and sanctioning the crimes, but also other non-judicial mechanisms, such as a truth commission and a unit for the search of disappeared persons.

It is undeniable that the peace agreement made possible a major social transformation: the FARC-EP no longer exists as an illegal armed group, but as a political party. Hostilities and conflict-related violence have been reduced. ${ }^{4}$

1 This research was funded by The Netherlands Organization for Scientific Research (Nwo) Grant Number 406-15-255. Juan Manuel Santos and Timoleón Jimenez, Agreement for Ending the Conflict and Building a Stable and Lasting, <www.altocomisionadoparalapaz.gov.co/ procesos-y-conversaciones/Documentos\%2ocompartidos/24-11-2016NuevoAcuerdoFinal .pdf $>$, accessed 31 October 2018.

2 Office of the Prosecutor of the International Criminal Court, Report on Preliminary Examinations Activities 2016, <www.icc-cpi.int/iccdocs/otp/161114-otp-rep-pe_eng.pdf >, accessed 31 October 2018.

3 Unidad para las Víctimas, Reporte Registro Único de Víctimas, <www.unidadvictimas.gov.co/ es/registro-unico-de-victimas-ruv/37394>, accessed 31 October 2018.

4 Fundación Pazy Reconciliación, Una Increíble Cifra de Reducción de La Violencia, <www.pares. com.co/wp-content/uploads/2017/04/Una-incre $\% \mathrm{C}_{3} \%$ ADble-cifra-de-reducci\% $\mathrm{C}_{3} \% \mathrm{~B}_{3}$ nde-la-violencia.pdf $>$, accessed 1 November 2017. 
On 13 October 2017, the Special Verification Mission of the United Nations handed over armaments and ammunition to the Colombian government that were yielded up by approximately 7,00o former FARC-EP members as the result of their demobilisation. ${ }^{5}$

The peace agreement, and particularly how perpetrators are to be punished, has also triggered very critical reactions. One of the main controversies revolves around the lack of long imprisonment terms and the use of restorative sanctions for the most serious crimes. Leaders of the opposition have fiercely rejected the accord since those considered the most responsible will not be sentenced to prison terms. According to them, this violates national and international standards of justice. ${ }^{6}$ Others, such as former President Juan Manuel Santos, stated that the peace deal represents peace without impunity since those most responsible will be punished, even if using restorative sanctions. ${ }^{7}$ From a more pragmatic perspective, it is considered as the only alternative to war. ${ }^{8}$

Penal measures are shaped by their social and historical context and, at the same time, they influence their social environment. ${ }^{9}$ Criminal punishment ${ }^{10}$ as a response to wrongdoing is always a context-dependent exercise. ${ }^{11}$ Thus,

$5 \quad$ Misión de Verificación de las Naciones Unidas en Colombia, Entrega formal al gobierno nacional del material resultado de la inhabilitación y destrucción de todo el armamento y munición de las FARC-EP que se encontraba resguardado en el depósito general de armamento de la Misión, <https://colombia.unmissions.org/entrega-formal-al-gobiernonacional-del-material-resultado-de-la-inhabilitaci $\% \mathrm{C}_{3} \% \mathrm{~B}_{3} n$-y-destrucci $\% \mathrm{C}_{3} \% \mathrm{~B} 3 n$-de>, accessed ${ }_{31}$ October 2018.

6 Álvaro Uribe, Oppenheimer: Entrevista a Álvaro Uribe, <http://edition.cnn.com/videos/ spanish/2013/11/18/cnnee-oppenheimer-alvaro-utibe-intv.cnn>, accessed 31 October 2018; Procuraduría General de la Nación, La paz no lo justifica todo, mínimos penales para máximos responsables, <www.procuraduria.gov.co/portal/media/file/200815DOCUMENTO .pdf $>$, accessed $3_{1}$ October 2018.

7 Juan Manuel Santos, Discurso de Juan Manual Santos en la firma de los acuerdos de paz, $<$ www.youtube.com/watch?v=dhtDNHKwxTQ $>$, accessed 31 October 2018.

8 Hernando Gómez, Perdonar todos los crímenes y a todos los criminales, <www.razonpublica.com/index.php/conflicto-drogas-y-paz-temas-30/9299-perdonar-todos-los-crimenesy-a-todos-los-criminales.html>, accessed 31 October 2018.

9 David Garland, Punishment and Modern Society. A Study in Social Theory (Oxford University Press, Oxford, 1990).

1o Following Garland, this article understands criminal punishment as 'the legal process whereby violators of the criminal law are condemned and sanctioned in accordance with specified legal categories and procedures'; the category includes processes of law-making, conviction, sentencing and the administration of penalties. Ibid., p. 17.

11 Colleen Murphy, 'Transitional Justice, Retributive Justice and Accountability for Wrongdoing', in Claudio Corradeti, Nir Eisikovits and Jack Rotondi (eds.), Theorizing Transitional 
it can only be properly understood and evaluated by considering a wider historical, societal and political context, in which it is enacted and implemented. In complex contexts of political transitions, when societies attempt to move from war to peace, penal policies heavily depend on political and societal factors triggering and driving the political transformation. In the case of peace negotiations to end an armed conflict, criminal punishment for past atrocity crimes (or the lack thereof) is often at the core of political discussion; it is not only shaped by the transitional context but it also conditions the transition and is thus central to its outcome. It is punishment in transition. It is complex and intricate.

The relationship of punishment and peace negotiations is commonly framed by the well-known dilemma of 'justice versus peace'. When negotiating peace, the problem of criminal punishment is often approached as a binary choice between prosecutions, trial and incarceration or broad amnesty for perpetrators. ${ }^{12}$ According to legalists, traditional prosecutions and sanctions for past grave human rights violations and international crimes are not only desirable but also necessary elements of justice. ${ }^{13}$ The demands for full judicial adjudication of criminal responsibility entailing proportionate punishment and subsequent incarceration, are, however, often confronted by moral challenges and pragmatic limitations. In fact, those alleged perpetrators, often sitting at the negotiating table, may agree to peace conditionally on receiving amnesties or pardons. ${ }^{14}$ Moreover, only a handful of perpetrators can be actually prosecuted and sanctioned given the scarcity of resources at hand, which must be administered to cover other societal and individual needs in a post-conflict setting. Therefore, securing criminal accountability and punishment as part of peace negotiations has proven to be almost impossible in practice.

Justice (Ashgate, Farnham, 2015) p. 59; Antony Duff, Punishment, Communication and Community (Oxford University Press, Oxford, 2001).

12 Priscilla Hayner, Centre for Humanitarian Dialogue and International Center for Transitional Justice, Negotiating Justice. Guidance for Mediators, <http://peacemaker.un.org/ sites/peacemaker.un.org/files/NegotiatingJustice_Hayner2009.pdf>, accessed ${ }_{31}$ October 2018.

13 Colleen Murphy, The Conceptual Foundations of Transitional Justice (Cambridge University Press, Cambridge, 2017) p.7; Lisa Laplante, 'Outlawing Amnesty: The Return of Criminal Justice in Transitional Justice Scheme', 49 Virginia Journal of International Law (2009) 915-984.

14 International Council of Human Rights Policy, Negotiating Justice? Human Rights and Peace Agreements, <www.ichrp.org/files/reports/22/128_report_en.pdf>, accessed 4 November 2017. 
Given these unique and often contradictory legal, moral, political and pragmatic considerations, punishment in transition does not readily resemble punishment 'as we know it' in times of stable democracies. ${ }^{15}$ Punishment in transition is not only operating in a context of transition, but is also in transition itself, changing and being moulded according to new and challenging social and political needs. While being a complex phenomenon, penal policies in times of political transition are generally understudied, ${ }^{16}$ in particular when it comes to transitions from war to peace, which are negotiated by former warring parties. This article seeks to fill this gap. It analyses the most recent case of negotiated punishment in transition stipulated in the peace agreement reached in November 2016 by the Government of Colombia and the FARC-EP. For the first time in peace-making history, the parties agreed on provisions for the adjudication of criminal responsibility and the enforcement of criminal sanctions. ${ }^{17}$

This article first explains what it understands by a 'context of political transition' to place the Colombian experience of negotiated punishment in transition in a broader analytical framework of transitional justice. The context of political transition encompasses a setting in which past political, collective and widespread criminality, which commonly amounts to international crimes and grave human rights violations, is being addressed while new political power structures are being created or consolidated. In this context, broad societal goals such as justice, democracy, rule of law or reconciliation are pursued while at the same time they are being debated and contested. Section two argues that in order to understand punishment negotiated in such volatile and complex contexts, a sociological analysis of punishment is necessary to reflect its unique social, cultural and political circumstances. In the third section, this article zooms in on the Colombian peace agreement with the FARC-EP. It describes characteristics of the Colombian political transition triggered by the peace accord, including dynamics of the conflict and the violence, and the objectives pursued by the accord. It describes the punishment agreed by the parties, highlighting the special sanctioning regime. This section argues that from a sociological perspective such punishment can be seen as a compromise

15 Murphy, supra note 11.

16 Leonidas Cheliotis and Sappho Xenakis, 'Punishment and Political Systems: State Punitiveness in Post-Dictatorial Greece', 18 Punishment and Society (2016) 268-300.

17 Leslie Vinjamuri and Aaron Boesenecker, Centre for Humanitarian Dialogue, Accountability and Peace Agreements. Mapping Trends from 1980 to 2006, <www.files.ethz.ch/ isn/39727/0907_Accountabilityreport.pdf>, accessed 31 October 2018; Vicenç Fisas, School for a Culture of Peace, Yearbook on Peace Processes 2016, <http://escolapau.uab.cat/index. php?option=com_content $\&$ view $=$ article $\&$ id $=916 \% 3$ Aanuario-de-procesos-de-paz-2016 \&catid $=67 \% 3$ Aanuarios\&Itemid=119\&lang=en $>$, accessed 31 October 2018. 
reached within a wider bargaining process, which is difficult to evaluate using traditional theories of criminal punishment, such as retribution, deterrence or incapacitation. Finally, drawing on the Colombian experience, this article on a general level explores particularities of punishment in transition, when designed in contexts of peace negotiations. It proposes a list of contextual factors to analyse the design, type and severity of punishment negotiated during processes, when political transition is being triggered and conditioned by a peace agreement.

In order to understand the design, implementation and challenges of punishment in transitions triggered by peace negotiations and to situate it in a broader analytical framework, it is first essential to outline the constitutive elements of a political transition. To do so, this article mainly draws upon literature from the field of transitional justice, which is a multi- and inter-disciplinary field of research studying the ways in which societies deal with past mass atrocity crimes, i.e. grave human rights violations and international crimes, in their efforts to democratise after armed conflict or repression. The problem of doing justice, and particularly of doing criminal justice after atrocities, including prosecutions and punishment, has been central to the work of many transitional justice scholars. ${ }^{18}$

The post-conflict or post-repression contexts in which atrocity crimes are addressed are known to be constrained, polarised, fragile and resistant to change. ${ }^{19}$ While the wording 'transitional context' is commonplace in this body of scholarship, ${ }^{20}$ the constitutive elements of such context are rarely explored. ${ }^{21}$ In order to understand the design, justification and application of

18 Naomi Roth-Arriaza, 'After Amnesties Are Gone: Latin American National Courts and the New Contours of the Fight Against Impunity', 37 Human Rights Quarterly (2015) 341-382.

19 International Center for Transitional Justice, What is Transitional Justice?, <www.ictj .org/sites/default/files/ICTJ-Global-Transitional-Justice-20og-English.pdf.>, accessed 1 November 2018.

20 Makau Mutua, 'What Is the Future of Transitional Justice?', g International Journal of Transitional Justice (2015) 1-9; Yeliz Budak, 'Dealing with the Past: Transitional Justice, Ongoing Conflict and the Kurdish Issue in Turkey', 9 International Journal of Transitional Justice (2015) 219-238.

21 Christine Bell, "Transitional Justice, Interdisciplinarity and the State of the "Field" or "Non-Field", 3 International Journal of Transitional Justice (2009) 5-27; Murphy, supra note 13 . 
punishment in negotiated transitions, however, the following three general features of such contexts are of essence. First, the character of the crimes, which are being punished. Second, the political environment in which punishment is designed and implemented, and, third, the future societal goals pursued by the concerned society and to which punishment policies are also oriented. These elements are briefly explained below.

Crimes addressed within a context of transition are widespread, collective and politically motivated. They are political in nature and generally 'carried out by the state (or with the permission of the state) or by actors fighting the de facto authorities to further political objectives. ${ }^{22}$ This is opposed to ordinary criminality, in which usually personal ends are pursued, ${ }^{23}$ even when offenses are committed through organisations. The violence is of a collective nature because it is committed by a multiplicity of perpetrators against a multiplicity of victims; it is committed 'by groups against groups.' ${ }^{24}$ There is a wide range of wrongdoers, including not only killers, rapists and other hands-on perpetrators, who are usually large in number, but also conflict entrepreneurs and leaders. The violence also targets victims en masse, sometimes based on discrimination; victims are dehumanised and selected because of their group membership. ${ }^{25}$ Furthermore, the crimes are of a widespread nature. The wrongdoing is not isolated but forms part of a 'broader pattern of actions and institutional structures that systematically diminishes the status of certain individuals or groups. ${ }^{26}$ Under international law, the atrocities can amount to grave human rights violations, crimes against humanity, war crimes and even genocide (international crimes). ${ }^{27}$

The characteristics of past crimes heavily impact upon the design and implementation of punishment. Resources to prosecute, judge and enforce criminal sanctions are generally limited, especially compared to the scale of the crimes and the subsequent societal and material destruction. Practical impediments to the application of criminal punishment are manifold. ${ }^{28}$ For instance, the justice system can be overburdened by the vast volume of crimes

\footnotetext{
22 Murphy, supra note 13, p. 52.

23 Ibid., p. 53.

24 Mark Drumbl, Atrocity, Punishment and International Law (Cambridge University Press, Cambridge, 2007) p. 26.

25 Ibid., pp. 41-2; Murphy, supra note 11, p. 64; Frank Haldemann, 'Another Kind of Justice: Transitional Justice as Recognition', 41 Cornell International Law Journal (2008) 693.

26 Murphy, supra note 11, p. 64

27 Rome Statute of the International Criminal Court; Articles 6, 7 and 8.

28 Drumbl, supra note 24, p. 44 .
} 
and defendants, ${ }^{29}$ evidence may have been destroyed, state agents and public officials may not be trustworthy, public institutions might be corrupt or lack sufficiently trained and funded police and legal staff. ${ }^{30}$ In addition, other urgent social and economic problems are usually competing for scarce resources, which makes it virtually impossible to sanction every possible perpetrator for every possible crime. Therefore, mechanisms for the prioritisation of cases and for the selection of those to be punished - are often developed and extraordinary punishment modalities implemented. For instance, punishment may be focused only on those considered most responsible, i.e., those giving the orders to commit crimes. ${ }^{31}$ No transitional society has managed to implement criminal proceedings followed by punishment proportionate to the scale of suffering and harm for each and every perpetrator of such violence. ${ }^{32}$

The large-scale, political and complex character of the past violence undoubtedly affects the time of transition itself. Societies facing political transitions are usually immersed in situations of political instability and struggle for political consolidation. ${ }^{33}$ In these settings, the consolidation of a political order or the construction of new power structures is taking place. Political transitions from war to peace through peace negotiations constitute a paradigmatic example of a political transition. In times of transition, the political future of the community can be deeply uncertain ${ }^{34}$ and political authority remains contested. It may still not be clear who has the right to govern and to set and enforce norms of interaction. ${ }^{35}$ In contexts of transition from war to peace, new norms and political processes are being consolidated, ${ }^{36}$ including penal normative frameworks.

29 Office of the United Nations High Commissioner for Human Rights, Rule-Of-Law Tools for Post-Conflict States, Prosecution Initiative (HR/PUB/o6/4), <www.ohchr.org/Documents/ Publications/RuleoflawProsecutionsen.pdf $>$, accessed ${ }_{31}$ October 2018.

30 Murphy, supra note 13, p. 9 .

31 Xabier Aguirre, Prosecuting the Most Responsible for International Crimes: Dilemmas of Definition and Prosecutorial Discretion, <www.academia.edu/2571646/Prosecuting_the most_Responsible_for_International_Crimes_Dilemmas_of_Definition_and_Prosecutorial_Discretion>, accessed 31 October 2018; Claus Roxin, 'Crimes as Part of Organized Power Structures', 9Journal of International Criminal Justice (2011) 193-206. Pablo De Greiff, 'Theorizing Transitional Justice', in Jon Elster, Rosemary Nagy and Melissa Williams (eds.), Transitional Justice: Nomos LI (New York University Press, New York, 2012) p. 35 .

33 Murphy, supra note 11, p. 60.

34 Ibid., p. 64.

35 Ibid., p. 60.

$36 \quad$ Ibid., p. 64. 
Against the background of political transitions through peace negotiations, societies not only deal with the past but also look to the future and pursue broad societal goals, such as (further) democratisation, reconciliation or prosperity. ${ }^{37}$ Nevertheless, what these concepts mean in practice is constantly being debated and contested within these communities. ${ }^{38}$ These political objectives inform public decisions and shape public policies, including penal policies. In other words, in political transitions, whether they are negotiated or imposed unilaterally, punishment is often instrumental for social transformation and pursues a plethora of broader political and societal goals. Punishment is thus no longer an end in and of itself, or the reaction of a society to a criminal offence or an ethical response to the crimes. Instead, it is an instrument to achieve broader social goals.

\section{$3 \quad$ Understanding and Evaluating Punishment in Negotiated Transitions: The Necessity of a Sociological Approach}

In public imagination, criminal punishment for the most serious offences is commonly reduced to the use of incarceration. In fact, the use of different modalities of sanctions, such as home detention, community service, electronic monitoring, ${ }^{39}$ restorative measures, ${ }^{40}$ or neurotechnological treatments ${ }^{41}$ is still debated. This discussion is nevertheless incipient. In practice, international criminal courts and tribunals have only applied imprisonment as sanction for international crimes. ${ }^{42}$ This leads some to argue that incarceration is the only acceptable penalty for this type of crime regardless of the context in which punishment is embedded. ${ }^{43}$ Nevertheless, in contexts of political transition, criminal punishment, even for the gravest crimes, has either been

37 Ruti Teitel, Rethinking the Rule of Law after Communism (Central European University Press, Budapest, 2005).

38 Jon Elster, Rosemary Nagy and Melissa Williams (eds.), Transitional Justice: Nomos LI (New York University Press, New York, 2012) p. 28.

39 Jesper Ryberg, 'Punishment and Political Philosophy', in W. Thompson (ed.), Oxford Research Encyclopedia of Politics (Oxford University Press, Oxford, 2016), p. 10.

40 Andrew von Hirsch, Julian Roberts, Anthony Bottoms, Kent Roach and Mara Schiff (eds.), Restorative Justice and Criminal Justice: Competing or Reconcilable Paradigms? (Hart, Oxford, 2003).

41 Lene Bomann-Larsen, 'Voluntary Rehabilitation', 6 Neuroethics (2011) 65-77.

42 Barbora Holá and Joris Van Wijk, 'Life after Conviction at International Criminal Tribunals: An Empirical Overview', 12 Journal of International Criminal Justice (2014) 109-32.

43 Procuraduría General de la Nación, supra note 6. 
'sacrificed' for the sake of peace and reconciliation, ${ }^{44}$ criticised as being victor's justice, ${ }^{45}$ or shaped to promote the cessation of violence or the demobilisation of combatants, as in Colombia in 2005 (Law 975 of 2005) and again, more recently, in 2016. This raises the question, what theoretical tools exist to understand and eventually evaluate different modalities of criminal punishment of past atrocities? What constitutes a 'just criminal punishment' in contexts of political transition?

Studies on punishment in contexts of political transition discuss only two issues. Firstly, they question whether criminal punishment is an opposite reaction to atrocities. For instance, Murphy challenges the suitability of 'legal punishment' to hold perpetrators accountable for past wrongs. For her, other kinds of responses may in fact be more apt for dealing with wrongdoers. ${ }^{46}$ Similarly, Drumbl questions the extent to which 'ordinary' punishment applied by international criminal courts and tribunals is a suitable response for extraordinary, international crimes. ${ }^{47}$ Secondly, these authors discuss justifications of punishment in transition. Murphy argues that punishment in contexts of political transition cannot be justified as retributive given that this reasoning is meant to operate in circumstances of reasonably stable democracies. ${ }^{48}$ Along the same lines, Drumbl questions the applicability of conventional punishment justifications, such as retribution, or deterrence, for penalties handed out by the international criminal tribunals. ${ }^{49}$ Indeed, both retrospective and prospective theories of criminal punishment are insufficient -in and of themselves- to grasp the complexities of punishment in transition.

Retrospectively, criminal punishment is justified by giving offenders what they deserve, retribution. ${ }^{50}$ In this sense, penal desert is not only necessary but sufficient reason for punishment. Punishment is then offence-centred

44 Louise Mallinder, 'Can Amnesties and International Justice Be Reconciled?', 1 International Journal of Transitional Justice (2007) 208-230; Roth-Arriaza, supra note 18; Francesca Lessa, Tricia D. Olsen, Leigh A. Payne, Gabriel Pereira and Andrew G. Reiter, 'Overcoming Impunity: Pathways to Accountability', 8 International Journal of Transitional Justice (2014) $75^{-98}$.

Gary Bass, Stay the Hand of Vengeance: The Politics of War Crimes Tribunals (Princeton University Press, Princeton, 200o), p. 8.

46 Murphy, supra note 11.

47 Drumbl, supra note 24, pp. 23-45.

48 Murphy, supra note 13, pp. 84-96.

49 Drumbl, supra note 24, pp. 149-173.

50 David Dolinko, 'Punishment', in Deigh John and David Dolinko (eds.), The Oxford Handbook of Philosophy of Criminal Law (Oxford University Press, Oxford, 2011) 403-440; Kieran McEvoy and Louise Mallinder, 'Amnesties, Transitional Justice and Governing through 
and seen per se as an appropriate response to crime, regardless of its consequences. ${ }^{51}$ Under this logic, the penal distribution should follow the principle of proportionality between the seriousness of a crime and the severity of the punishment. According to the proportionality metric, the graver the offense, the more severe the sanction. ${ }^{52}$ This approach is nevertheless problematic as to what proportionate punishment in practice entails. Usually, it is argued that the offender deserves harsh or burdensome treatment. ${ }^{53}$ More recently, other authors have argued that the wrongdoer deserves censure or condemnation ${ }^{54}$ and this is precisely what distinguishes a criminal punishment from other types of burden.

Theoretically, penal distribution according to a desert-based approach requires knowing why a crime is more (or less) serious than others and why a penalty is more (or less) severe than others. ${ }^{55}$ Generally, the gravity of a crime is determined on the basis of the harm caused and the culpability of the offender. ${ }^{56}$ Furthermore, in the case of imprisonment, the severity of the sanction is usually measured in terms of its duration. ${ }^{57}$ However, in theory, retributivism also accepts different types of punishment as long as the ordinal proportionality (i.e. more serious crimes should be punished more severely than less serious offenses) is preserved. ${ }^{58}$ According to a retributive logic, international crimes deserve the most severe penalties available. ${ }^{59}$ However, purely retributive reasoning when it comes to punishing international crimes can be challenged for at least two reasons. First, it is debatable whether a punishment reflecting the vast amount of harm and culpability of offenders convicted of international

Mercy', in Jonathan Simon and Richard Sparks (eds.), The Sage Handbook of Punishment and Society (SAGE Publications Ltd, London, 2013) 434-462.

Duff, supra note 11, p. 19.

$5^{2}$ Drumbl, supra note 24, p. 155 .

53 Lawrence Davis, 'They Deserve to Suffer', 32 Analysis, Oxford Academics (1972) 136-140; John Kleinig, Punishment and Desert (Martinus Nijhoff, The Hague, 1973), p. 49.

Christopher Bennett, The Apology Ritual (Cambridge University Press, Cambridge, 2008); Duff, supra note 11; Dan Markel, 'What Might Retributive Justice Be?', in Mark White (ed.), Retributivism: Essays on Theory and Policy (Oxford University Press, New York, 2011) 49-72; Bill Wringe, An Expressive Theory of Punishment (Palgrave MacMillan, Basingstoke, 2015).

55 Andrew von Hirsch, Censure and Sanctions (Clarendon Press, Oxford, 1993), p. 29.

56 Ibid.; Alec Walen, 'Retributive Justice', in Edward Zalta (ed.), The Stanford Encyclopedia of Philosophy (Metaphysics Research Lab, Stanford University, 2016), <https://plato.stanford.edu/archives/win2016/entries/justice-retributive/>, accessed 1 November 2018.

57 Von Hirsch, supra note 55 .

58 Andrew von Hirsch, 'Punishments in the Community and the Principles of Desert', 20 Rutgers Law Journal (1989) 595-616.

59 Drumbl, supra note 24, p. 60. 
crimes could ever exist. ${ }^{60}$ Additionally, a strict retributive logic makes it impossible to argue that in some contexts a lack of punishment or its deviation from the proportionality standard (too severe or too lenient) may be acceptable if justified by other future oriented penal goals, such as deterrence or rehabilitation, or broader societal goals. Under retributive logic, broader (positive) societal goals pursued in many contexts of political transition, such as the termination of armed confrontation or political stability, ${ }^{61}$ should not impact upon the proportionality equilibrium.

According to the prospective theories of punishment, punishment is justified by protecting societies from future crimes through any of the following: deterrence, rehabilitation or incapacitation. ${ }^{62}$ These theories are based on utilitarian, ethical considerations, according to which the right act is the one that produces the best consequences. ${ }^{63}$ Therefore, justified sanctions are those that maximise the beneficial effects produced by the punishment, while keeping the suffering of the wrongdoer to a necessary minimum. ${ }^{64}$ However, in practice, utilitarian justifications are contingent on empirical evidence on whether a specific punishment indeed causes the intended outcomes and whether these can be achieved by less harmful means. This evidence is complex and very difficult to gain. ${ }^{65}$ There are additional challenges to utilitarian theories in the case of punishment of international crimes. ${ }^{66}$ Some question the uncritical adoption of the utilitarian theories from the realm of ordinary criminality. ${ }^{67}$ Perpetrators of international crimes arguably do not necessarily counterbalance the risk of prosecution with the (political or ideological) gains ensuing from the commission of the crimes, as deterrence theory would

6o Stuart Beresford, 'Unshackling the Paper Tiger - The Sentencing Practices of the Ad Hoc International Criminal Tribunals for the Former Yugoslavia and Rwanda', 1 International Criminal Law Review (2001) 33-90.

61 Jesper Ryberg, 'Mass Atrocities, Retributivism and the Threshold Challenge', 16 Res Publica (2010) 169-179.

62 Dolinko, supra note 50, p. 407.

63 Jesper Ryberg and Angelo Corlett (eds.), Punishment and Ethics: New Perspectives (Palgrave MacMillan, Basingstoke, 2010), p. 4.

64 Ibid., p. 12.

65 Ibid., p. 5 .

66 Leslie Vinjamuri, 'Deterrence, Democracy, and the Pursuit of International Justice', 24 Ethics \& International Affairs (2010) 191-2011.

67 David Wippman, 'Atrocities, Deterrence, and the Limits of International Justice', 23 Fordham International Law Journal (1999) 473-88; Kate Cronin-Furman, 'Managing Expectations. International Criminal Trials and the Prospects for Deterrence of Mass Atrocity', 7 International Journal of Transitional Justice (2013) 434-54. 
assume. ${ }^{68}$ And even if they do so, they most probably view the risk of prosecution as negligible. ${ }^{69}$ Others emphasise a lack of empirical proof regarding the deterrence of international crimes via punishment. Indeed, empirical data in this respect is scarce ${ }^{70}$ and difficult to collect. Moreover, if data is available, the establishment of a valid and reliable correlation between the actions of criminal tribunals such as the International Criminal Court, and the fluctuation of violence is problematic. ${ }^{71}$

Therefore, a restorative approach to dealing with past atrocities in the context of political transition is often juxtaposed as a more appropriate response compared to criminal punishment. Restorative justice seeks to repair the harm caused by crime, which is conceptualised as a conflict between offenders and victims. ${ }^{72}$ It emphasises the humanity of both offenders and victims and aims to engage all stakeholders, including community members, in resolving the conflict. ${ }^{73}$ It seeks to repair social connections and relationships rather than retribution. ${ }^{74}$ In addition, it aims at restoring the family and collective ties of both victims and perpetrators. ${ }^{75}$ Restorative justice is materialised within criminal procedures through different acts, such as possibilities for economic and

68 Ralph Henham, Punishment and Process in International Criminal Trials (Ashgate, Farnham, 2005), p. 141; Theodor Meron, 'From Nuremberg to The Hague', 149 Military Law Review (1995) 110.

69 Wippman, supra note 67, p. 479.

70 William Schabas, The International Criminal Court: A Commentary on the Rome Statute (Oxford University Press, Oxford, 2010), p. 61.

71 International Nuremberg Principles Academy, Two Steps Forward, One Step Back: The Deterrent Effect of International Criminal Tribunals, <www.nurembergacademy.org/filead$\mathrm{min} / \mathrm{media} /$ pdf/publications/DETERRENCEPUBLICATION.pdf>, accessed 31 October 2018.

72 Lucia Zedner, 'Reparation and Retribution: Are They Reconcilable?', 57 The Modern Law Review (1994) 228-250.

73 Tony F. Marshall, Restorative Justice: An Overview (Home Office Research Development and Statistics Directorate, London, 1992), <https://276dd27f-a-62cb3a1a-s-sites .googlegroups.com/site/monofinal/legitimidade-sistema-penal/occ-resjus.pdf? attachauth=ANoY7cpUD_FoKCjYLBNpxcwR604QRNqKY8mnMh_UxkaXnPikeMJVzQDb4Teb2Pq76cWP4-1IJnkZ6vH94Mui3vihrZwN5szi_PB4opcCK6Mx69Iw46IzXMFWBCbIUuTYy3i4h5hzqOKNetHsTaJqogvgQc4cAxJZkkbHPI-Xpl3IXuAPjSGB12G4thhfKeFwdaPo2oqA8R8ikDS1Ouj2aVRMOOokC5sMx6owdZwzPgn_HgKtqdEVClsHN4GuvbAfUn

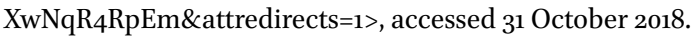

74 Martha Minow, Between Vengeance and Forgiveness (Beacon Press, Boston, 1992), p. 92.

75 John Braithwaite, 'Restorative Justice and a Better Future', in Gerry Johnstone (ed.), $A$ Restorative Justice Reader (Routledge, New York, 2003) 83-97. 
symbolic acts of reparations for survivors and for devastated communities, ${ }^{76}$ acts of reintegration of offenders into the community through, for instance, public acknowledgement and apologies. ${ }^{77}$ According to restorativists, societies can heal deep wounds through dialogue between victims and perpetrators and especially through the concession of pardons, which are believed to facilitate the achievement of peaceful social order. ${ }^{78}$ Under the restorative justice paradigm, international crimes could be pardoned if that would mean social ties could be rebuilt. ${ }^{79}$ Nevertheless, to forgive and forget international crimes is in practice problematic for several reasons, including the international legal obligation to prosecute and punish gross human rights violations and international crimes, and the victims' rights to remedies. ${ }^{80}$

Murphy recently coined a new theory of transitional justice, which is mainly concerned with the 'just pursuit of societal transformation'.81 According to the author, this pursuit becomes bound up with the process of responding to past wrongs. Nevertheless, criminal punishment is not the only and certainly not the best reaction. Instead, there is a wide range of responses to past atrocities, directed to both victims and perpetrators, which might be appropriate and fitting given the character of violence and the context of political transition. In such circumstances, for Murphy, the core issue of punishment is not equivalent to the core issue of retributive punishment. Therefore, criminal punishment, in isolation, cannot satisfy the demands of justice. Furthermore, even when implemented in conjunction with other non-punitive measures, the design, implementation and evaluation of such punishment in transition must be holistic. It must, on the one hand, contribute to the societal transformation pursued, and, on the other hand, respond to: (i) particular moral aims, such as repudiation of the wrongs and pursuing accountability, (ii) the specific nature of the wrong being addressed, (iii) the complex relationship among victims, perpetrators and third parties, and (iv) the particular cultural contexts in which the response takes place. ${ }^{82}$

76 Minow, supra note 74, pp. 91-117.

77 Ibid.

78 Rodrigo Uprimny and Maria Saffon, Transitional Justice, Restorative Justice and Reconciliation. Some Insights from the Colombia Case, < https://cdn.dejusticia.org/wp-content/uploads/2017/04/fi_name_recurso_55.pdf $>$, accessed 1 November 2018.

Ibid.

8o Rodrigo Uprimny, María Saffon, Catalina Botero and Marino Esteban, ¿Justicia transicional sin transición? Verdad, justicia y reparación para Colombia, <www.dejusticia.org/wpcontent/uploads/2017/04/fi_name_recurso_201.pdf >, accessed 31 October 2018.

81 Murphy, supra note 13, pp. 160-192.

82 Ibid. 
Murphy's transitional justice theory highlights that the first step for evaluating punishment is to grasp the factual, contextual factors and circumstances of a transitional moment. This is to say, to understand the complexities and nuances of the society facing the political transition, the transition itself and how punishment interplays therein. Punishment in transition needs to be contextualised before being evaluated. In this respect, therefore, a sociological perspective on punishment offers a useful lens. This perspective highlights the necessity of appreciating punishment taking into consideration its role, significance and effects in social life. ${ }^{83}$ For Garland, 'we need to know what punishment is in order to think what it can and should be'. ${ }^{84}$ Generally, punishment takes part in a complicated and multi-faceted reality and, in order to grasp its essence it is in need of a thorough contextualisation. In order to do this contextual analysis, it is necessary to explore the many dynamics and forces in which punishment interplays to build up a complex picture of the circuits of meaning and action, within which it functions. ${ }^{85}$

Punishment as a social institution implies many different sorts of relationships, which are in constant conflict, tension and compromise. Therefore, the large number of conflicting forces at work ${ }^{86}$ need to be deconstructed, described and analysed to grasp the meaning and function of punishment. For Garland, 'these swarming circumstances are only ever resolved into particular outcomes by means of struggles, negotiations, actions and decisions, which are undertaken by those involved in the making and implementation of policy'. ${ }^{87} \mathrm{~A}$ sociological perspective on punishment is particularly apposite for deconstructing, describing and analysing a penal reaction to atrocities enacted and implemented in times of political transitions. It draws attention to the context and situates the phenomenon in its social, cultural and political environs. ${ }^{88}$ Punishment in transition is a particularly complex phenomenon, which cannot be decontextualised and evaluated according to a single valuebased theory of punishment, which, as demonstrated above, can be deeply problematic.

\footnotetext{
83 Garland, supra note 9 .

84 Ibid., p. 10.

85 Ibid., p. 17.

86 Ibid., p. 285 .

87 Ibid.

88 Calvin Morrill, John Hagan, Bernard Harcourt, and Tracey Meares, 'Seeing Crime and Punishment through a Sociological Lens: Contributions, Practices, and the Future', Yale Law School Faculty Scholarship Series (2005) 289-323.
} 


\section{Punishment in Transition Negotiated in the Colombian Peace Agreement with the FARC-EP}

In practice, political transitions are rarely clear-cut. Colombian efforts to come to terms with its multi-factored and multi-layered internal armed conflict through bilateral peace talks with different armed groups have been referred to as an example of 'transition without transition' ${ }^{89}$ The expression highlights the challenges of piecemeal attempts to reach peace partially and separately with a violent group while confrontation continues with a different one. While armed conflict is not completely over in the country, the peace agreement with the FARC-EP is a clear example of a political transition. The FARC-EP rebels were one of the main actors of the conflict initiated in the 196os. In 2018 they are a political party, which actually ran for the most recent congressional and presidential elections. This section presents characteristics of the negotiated transition with the FARC-EP in Colombia and contextualises punishment negotiated to address conflict-related crimes within the newly established Special Jurisdiction for Peace.

\subsection{The Political Transition Triggered by the Peace Negotiation with the FARC-EP}

Over the past 50 years, Colombia has experienced extreme violence, often amounting to international crimes and grave human rights violations, perpetrated by left and right-wing armed groups, and by state agents..$^{90}$ All armed actors have attacked the civilian population. For instance, guerrilla forces have kidnapped, committed acts of pillage, recruitment of children, forced displacement, and planted landmines throughout the country. The military forces have committed acts of torture, extrajudicial detentions and executions and enforced disappearances. ${ }^{91}$ The available statistics reveal the grave nature and large scale of conflict-related crimes. Up to October 2018, there have been $8,760,290$ officially registered victims. Approximately 220,000 persons have been assassinated for political reasons between 1958 and 2012.92 According to

89 Uprimny et al., supra note 80.

9o Leftists armed groups, such as the FARC-EP and the Ejército de Liberación Nacional (ELN) and paramilitary forces such as the Autodefensas Unidas de Colombia (AUC).

91 Centro Nacional de Memoria Histórica, ;Basta ya! Colombia: memorias y dignidad. Imprenta Nacional, <www.centrodememoriahistorica.gov.co/descargas/informes2013/ bastaYa/basta-ya-colombia-memorias-de-guerra-y-dignidad-2016.pdf $>$, accessed 31 October 2018 .

$92 \quad$ Ibid. 
the Office of the Prosecutor of the International Criminal Court (отр-ICC), many of these acts allegedly amount to crimes against humanity and war crimes. ${ }^{93}$

In order to be able to fully understand the peace negotiations, and contextualise the Colombian punishment in transition, it is necessary, if only briefly, to outline its extremely complex historical, socio-economic, political and institutional context. Various factors such as the political agenda of the FARC of fighting for social justice; their reliance on and furtherance of illegal economies, such as drug trafficking; the corrupt political and justice system in Colombia or involvement of foreign States (such as Us) and other actors, are often considered to have fuelled and prolonged the armed conflict. ${ }^{94}$ Indeed, there were several unsuccessful attempts to end the conflict and to negotiate peace. The first negotiation with a faction of the FARC-EP took place in 1984 and there was another failed attempt in 1999. From that time on, at least four relevant sets of peace talks have taken place with other guerrilla groups and a paramilitary group ${ }^{95}$ leading to a partial cessation of hostilities and to granting of amnesties, pardons and reduced terms of imprisonment (see, for instance, Law 77 of 1989 and Law 975 of 2005). In 2012, the government engaged in peace talks with the FARC-EP again and a final agreement was reached in 2016.

Colombian scholars have asserted that military considerations on both sides played a major role in initiating, continuing and bringing the recent set of peace negotiations to a successful end. ${ }^{96}$ From 2002 to 2012, the 'war model' of the FARC-EP had broken down for political, military and technological reasons. The State military forces were successfully implementing an effective new strategy consisting of attacking high-level guerrilla units and their funding sources. During those years, the FARC-EP lost most of its leaders and saw the highest rate of individual demobilisations in its history. In response, the guerrilla group changed its war model to a more strategically defensive one, for instance by targeting the mining and energy sectors and putting more

93 Office of the Prosecutor of the International Criminal Court, supra note 2.

94 Comisión Histórica del Conflicto y sus Víctimas, Contribución al entendimiento del conflicto armado en Colombia, <www.altocomisionadoparalapaz.gov.co/mesadeconversaciones/ PDF/Informe\%2oComisi_n\%2oHist_rica\%2odel\%2oConflicto\%2oy\%2osus\%2o V_ctimas.\%2oLa\%20Habana\%2C\%2oFebrero\%2ode\%202015.pdf>, accessed 31 October 2018.

95 In 1990 with the Movimiento 19 de Abril (M-19) guerrilla group; from 1991 to 1994 with five minor guerrilla groups, and in 2003 with the Autodenfensas Unidas de Colombia (AUC).

96 Ariel Avila, Fundación Pazy Reconciliación, Cómo es eso de negociar en medio del conflicto?, $<$ www.pares.com.co/carrusel/observatorio-violencia-politica-en-colombia-2013-2017-2/>, accessed 4 November 2017 . 
emphasis on their political and ideological aspirations. The FARC-EP managed to recuperate militarily to an extent, but it did not continue growing before and during the negotiation process. ${ }^{97}$

By 2012, both the FARC-EP and the government realised their inability to achieve a military victory. This, together with other considerations, influenced the decision to go back to the negotiating table. For instance, the FARC-EP renewed leadership saw leftist politicians (Bolivia, Ecuador, Venezuela), and even former combatants (Uruguay and Brazil) coming to power in neighbouring countries. On the other hand, the government saw the risk of facing a guerrilla group lacking a strong political leadership, without which it would not be possible to achieve any agreement. Moreover, the implementation of the governmental political agenda of modernisation and focus on issues such as rural development, political participation and drug trafficking was, to an extent, dependent on the cooperation of the FARC-EP. Furthermore, the ethical issue of avoiding the loss of lives and suffering of members of both the military and of the guerrilla groups must not be underestimated. ${ }^{98}$

In 2012, the parties defined a negotiation agenda. It included six items, namely: (i) rural reform and agrarian development policy, (ii) political participation, (iii) illicit drugs policy, (iv) end of conflict, including demobilisation and disarmament, (v) rights of victims, including criminal accountability and punishment, and (vi) implementation and endorsement. The fifth point was arguably one of the most challenging and politically charged parts of the negotiations. Negotiating parties publicly announced that justice for victims was not limited to criminal accountability and that victims' rights included acknowledgement of responsibility, truth, reparation, guarantees of non-repetition and security and reconciliation. ${ }^{99}$ This steered public debate on the extent to which the parties would comply with international obligations to prosecute

97 Mario Aguilera, 'Las farc: auge y quiebre de su modelo de guerra', 26 Análisis Político (2013) 85-111; L. Martínez, Los Cambios en la Estrategia Militar de Las FARC en la Última Década, Fundación Paz y Reconciliación, <www.pares.com.co/paz-y-posconflicto/grupos-armados-ilegales/farc/los-cambios-en-la-estrategia-miliar-de-las-farc-en-la-ultimadecada/>, accessed 26 October 2017.

98 Kristian Herbolzheimer, Norwegian Peacebuilding Resource Centre, Innovations in the Colombian Peace Process, <www.c-r.org/downloads/NOREF_CR_Report_Colombia\%20 Innovations_final.pdf $>$, accessed 31 October 2018.

99 Government of Colombia and FARC-EP, Declaración de Principios para la Discusión del Punto 5 de Agenda: Víctimas, <www.altocomisionadoparalapaz.gov.co/mesadeconversaciones/PDF/Comunicado\%2oConjunto\%2C\%2oLa\%2oHabana\%2C\%2007\%2ode\%20 junio\%2ode\%202014\%2C\%2oVersi_n\%2oEspa_ol.pdf>, accessed 31 October 2018. 
and sanction, as established in international treaties ratified by Colombia, particularly in the Rome Statute of the International Criminal Court. ${ }^{100}$

During the negotiations, two relevant external actors were included to personally present their views and suggestions. Firstly, a group of sixty victims affected by the FARC-EP guerrilla, state agents and paramilitary groups, chosen by the United Nations, met face to face with the negotiators. ${ }^{101}$ Secondly, negotiating parties held meetings with representatives of eight most important companies of the country (Promigás, Grupo Sura, Bancolombia, Grupo Manuelita, Alquería, Carvajal, Nutresa, EAFIT). In addition, the negotiation was opened, from beginning to end, to civil society members to submit their views. Approximately 63,000 submissions were received, out of which 27,000 related to issues of victims' rights. ${ }^{102}$ Also, four public forums were held in Colombia. According to the Colombian Government, approximately 3,000 victims participated in these meetings. ${ }^{103}$ Final rapporteurs on each forum gathered more than 22,000 additional proposals which were taken directly to the negotiators. ${ }^{104}$

A first peace agreement was reached in September 2016. Subsequently, the peace accord was submitted to popular approval through a plebiscite conducted on 2 October 2016. In a surprising outcome, and for a narrow majority $(50,2 \%)$, Colombians voters rejected the agreement. Some commentators claimed that the main reason for the popular rejection was the extraordinarily lenient sanctions envisaged for perpetrators of atrocities. ${ }^{105}$ Indeed, the fact that guerrilla leaders might avoid imprisonment proved to be highly controversial. Nevertheless, other items of the accord were equally unpopular. For example, provisions to open the door for the political participation of former

100 Cf. provisions of the Rome Statute of the ICC ratified by Colombia in 2002; International Covenant on Civil and Political Rights, ratified in 1969; International Convention on the Elimination of All Forms of Racial Discrimination, ratified in 1981; Convention against Torture and Other Cruel, Inhuman or Degrading Treatment or Punishment, ratified in 1987; International Convention for the Protection of All Persons from Enforced Disappearance, ratified in 2012; and American Convention on Human Rights, ratified in 1973.

101 Andrés Ucrós, 'What Is the Colombian Peace Process Teaching the World?', 29 New England Journal of Public Policy (2017) 1-7.

102 Juanita Goebertus, Interview, International Center for Transitional Justice, <www.facebook.com/theICTJ/videos/10154838748584692/>, accessed 31 October 2018.

103 Ibid.

104 Ucrós, supra note 101.

105 Paul Williams, 'The Colombian Referendum: A Lesson on Peace without Justice', Huffington Post, <www.huffingtonpost.com/entry/the-colombian-referendum-a-lessonon-peace-without_us_57f7dgdfe4bogodecoe71064>, accessed 31 October 2018. 
members of the FARC-EP for the legislative elections of $2018^{106}$ and provide economic support for their reintegration process were controversial. In addition, some Colombians feared that the implementation of the agreement would usher in a castro-chavista communist catastrophe ${ }^{107}$ and a prominent conservative and religious sector contended that the mention of 'gender' as a relevant category and the protection of LGTB's rights within the agreement was evidence of an attack against family values.

Irrespective of the reasons for the plebiscite results, the Government reacted swiftly and the talks on the most controversial issues were re-opened. The signing of a new document took place in November 2016. This time, however, no popular vote was scheduled. The provisions on punishment were further clarified yet not fundamentally changed. For instance, conditions for the enforcement of sanctions were agreed upon and additional criteria to evaluate crimes that could be amnestied were included. The Government declared that the new renegotiated agreement would unite the deeply divided country. ${ }^{108}$ For the rebel group, this document reflected the limits of what they could reasonably concede. ${ }^{109}$ This new deal, nevertheless, still did not satisfy a strong political opposition.

In any case, negotiated criminal punishment, described in the next section, can neither be decontextualised from the difficult conflict history and crimes it is meant to address nor from the equally complex and nuanced national political and societal circumstances driving the transition and the broader societal and political goals it pursues.

\subsection{Punishment in the Peace Agreement: Special Jurisdiction for Peace}

The peace agreement includes the creation of a Comprehensive System to Satisfy Victims' Rights to Truth, Justice, Reparation and Non-Repetition. The Comprehensive system comprises judicial and non-judicial mechanisms, such as Special Jurisdiction for Peace (sJP), which is in charge of matters of criminal accountability for conflict-related crimes; a Truth Commission; a Unit for the Search of Disappeared Persons; and schemes for reparation and

106 Mauricio Vargas, Matar sí paga, <www.eltiempo.com/opinion/columnistas/mauricio-var gas/matar-si-paga-la-idea-que-se-debe-acabar-en-colombia-102492>, accessed ${ }_{31}$ October 2018.

107 Juanita León, Los temores del No: 4. El castrochavismo, <http://lasillavacia.com/historia/ los-temores-del-no-4-el-castrochavismo-58133>, accessed 31 October 2018.

108 Santos, supra note 7.

109 Timoleón Jimenez, Timochenko afirma que con el nuevo acuerdo "está triunfando la paz, $<$ www.cablenoticias.tv/vernoticia.asp?WPLACA=86644>, accessed 1 November 2018. 
non-repetition. These bodies operate in a coordinated manner through novel institutional and procedural frameworks.

The SJP is based upon five general principles. First, amnesties are granted for political crimes as defined under domestic criminal law, 110 including the act of rebellion and the killing of combatants. These acts are therefore exempted from criminal accountability and sanctions. Second, those crimes that cannot legally be amnestied shall be investigated and punished. These offenses comprise international crimes, namely genocide, crimes against humanity and war crimes. Third, with respect to these crimes a special set of sanctions with a strong restorative dimension is available for perpetrators who acknowledge their responsibility. Fourth, the sJP prosecutes and sanctions state agents, guerrilla members and third parties that directly or indirectly participated in the commission of international crimes. The system specifically targets those considered to be the most responsible. Fifth, participation in this accountability scheme is conditional. To receive reduced or restorative sanctions, defendants must comply with obligations related to truth, reparation and non-repetition. ${ }^{111}$

The SJP comprises of five new institutions: the Tribunal for Peace, in charge of delivering judgments and meting out punishments; three Chambers of Justice (Chamber for Acknowledgement of Truth and Responsibility, Chamber for the Definition of Legal Status and Chamber for Amnesties and Pardons); and one Investigative Unit.

The whole system is based on a logic of incentives and threats, which in turn, are mediated by conditions. The basic scheme is a combination of pull and push factors, aimed to compel perpetrators to behave in a certain way while at the same time to serve as a deterrent mechanism: If you do $x$ (cease

110 In Colombia, a political crime is a restricted category encompassing non-grave conducts committed against the State and the Constitutional order. See: Colombian Criminal Code, Articles $467-472$.

111 The legal framework of the Special Jurisdiction for Peace is comprised of the following norms: Acto legislativo or de 2017; Judgment C-674 de 2017 issued by the Colombian Constitutional Court and by which the Acto legislativo or de 2017 was revised and approved; Acto legislativo 02 de 2017; Ley 1820 de 2016; Judgment C-007 de 2018 issued by the Colombian Constitutional Court and by which the Ley 1820 de 2016 was revised and approved; Decreto Ley 277 de 2017; Judgment C-025 de 2018 issued by the Colombian Constitutional Court and by which the Decreto Ley 277 de 2017 was revised and approved and Ley 1922 de 2018. Furthermore, the bill "Proyecto de Ley Estatutaria número o8 de 2017, Senado - o16 de 2017, Cámara", was revised and approved by the Colombia Constitutional Court by judgement C-08o de 2018. Nevertheless, as of the end of October 2018, it is pending Presidential approval. 
violence and disclose and recognise truth), then the State will offer $y$ (restorative sanctions, amnesties and pardons) unless you do $z$ (not telling the truth and not contributing to reparation), in which case the State will take away $y$ and will apply $w$ (imprisonment) instead. The whole system was designed to operate in a way that a reasonably rational defendant, after weighing up the costs and benefits, will conclude that he or she has more to gain by cooperating with it rather than by avoiding it.

In practice, those alleged to be the most responsible perpetrators of grave human rights violations and international crimes that confess, tell the truth and acknowledge responsibility in a prompt, complete and detailed manner will receive restorative sanctions. These sanctions have two main characteristics. First, convicted persons will be subjected to a regime of 'effective restriction of liberty' for a period of between five to eight years. The 'effective restriction of liberty' consists of limiting and controlling the rights of free movement and residency. Second, sanctions are restorative by nature. For instance, in rural areas, they will require participation in or implementation of programs for: (i) reparation of displaced peasants, (ii) environmental protection, (iii) construction and reparation of infrastructure, (iv) rural development, waste disposal, electrification and improvement of communications, (iv) substitution of illegal crops, (v) development of infrastructure necessary for agricultural trade and (vi) removal and eradication of explosive remnants of war, unexploded weapons and landmines.

Defendants who belatedly confess the truth and acknowledge their responsibility will be subjected to reduced terms of imprisonment from five to eight years. The level of participation of an offender in a crime may mitigate the severity of the sanction. Accordingly, those considered not to be the most responsible may receive prison terms from two to five years. Furthermore, individuals who do not confess the truth or admit their responsibility, but are nonetheless found guilty, will face imprisonment from fifteen to twenty years, in contrast to the maximum penalty of sixty years they would face in the ordinary system of justice, according to Article 31 of Law 599 of 2004. The possibility of longer terms of imprisonment is meant to operate as a 'stick' or as a deterrent mechanism, while the avenue to reduced prison terms is the 'carrot' that seeks to motivate defendants to come forward and confess.

\subsection{Understanding the Punishment Controversy in Colombia}

The most controversial aspect of the Colombian punishment in transition turned out to be the substitution of potential lengthy imprisonment for perpetrators of international crimes with restorative sanctions. Critics rely on traditional justifications of punishment, i.e., retributive and utilitarian, to evaluate and question the envisaged sanction regime. Examples include assertions 
such as, 'the sanctions are gross and manifestly inadequate since they are not proportionate to the gravity of the crimes, (...) they are a comedy' 112 or 'total impunity will be the mother of new violence.'113 Indeed, Colombian criminal law is based on largely retributive considerations and severe incarceration terms are part of the criminal policy. ${ }^{114}$ Under ordinary circumstances, the Colombian criminal code provides for up to sixty years of imprisonment for conduct amounting to international crimes. Against this background, punishment, based on non-retributive and non-traditional bases, for the most serious violence and for those considered to be the most responsible is clearly unorthodox. Nevertheless, to claim that the Colombian agreement amounts to full impunity appears to be incorrect. The new sanctioning regime includes restrictions on the rights to liberty and residence and makes participation in social service projects mandatory for convicted perpetrators. Moreover, the sanctions depend on the ascertainment of criminal liability adjudicated by a special tribunal.

The sanctioning regime negotiated in Colombia, before being evaluated, needs to be contextualised within its transitional setting, as argued in Sections 2 and 3, and assessed accordingly. In particular, there are three key contextual factors essential for understanding punishment in the Colombian transition.

Firstly, as demonstrated in the statistics presented above, the crimes punished by the SJP are acts of mass atrocity violence perpetrated over a time span of 50 years, leaving behind mass destruction and multiplicity of victims. The violence implicated a multiplicity of individuals and actors in various roles and bearing different degrees of responsibility. In order to address crimes committed on such a wide scale within an ordinary criminal justice system, employing conventional criminal trials and penalties, would clearly be impossible. Creative solutions were necessary to ascertain at least a certain level of accountability, for as many perpetrators as possible. By incentivising defendants to come forward and uncover the truth for exchange of restorative or reduced sanctions, the punishment designed for the SJP reflects pragmatic considerations of pursuing justice in a negotiated transition from war to peace.

Secondly, punishment was designed within a peace negotiation with the largest guerrilla group of the country, which has proven capable of political

\footnotetext{
112 Procuraduria General de la Nación, supra note 6.

113 Uribe, supra note 6.

114 Colombian Criminal Code, Articles $3^{-4}$ and Constitutional Court of Colombia, Judgement C-144 of 1997.
} 
destabilisation and of large-scale violence with lethal impact. The agreement is the product of bargaining of two opposing armed forces that fought each other for more than half a century without one being able to defeat the other. ${ }^{115}$ Peace negotiations entail the finding of a common ground between opposite interests. ${ }^{116}$ In the Colombian case, the negotiations found common ground between the refusal of the rebels to finish peace negotiations completely deprived of their liberty ${ }^{117}$ and the obligation of the State to punish international crimes and grave human rights violations. This is 'a cooperative punitive solution' that does not necessarily entail deprivation of liberty and jailtime. The negotiating parties stated that they pursued as much justice as possible within the political moment. ${ }^{118}$ The question of punishment was negotiated as one additional piece of a bigger bargaining process, in which negotiators' interests on land redistribution, political participation, drug-trafficking issues, and justice and impunity were balanced against each other. Therefore, punishment cannot be isolated from all the other issues at the table and was arguably shaped and formed by the gains and losses of each party on the other items of the agenda.

Finally and relatedly, the punishment agreed upon by the Colombian government and the FARC-EP seeks to achieve broader societal goals, such as the achievement of a stable and durable peace, the promotion of peaceful coexistence in the country, cessation of hostilities, the prevention of new violence, the reintegration of former combatants and reconciliation. Moreover, since the SJP is part of the new system of administration of (transitional) justice, the promotion of the rule of law is also one of its key objectives. All these objectives were arguably considered and factored in by the negotiating parties when designing the SJP and its sanctioning regime.

\footnotetext{
115 Jimenez, supra note 109.

116 Colin Clarke and Cristopher Paul, RAND Corporation, From Stalemate to Settlement Lessons for Afghanistan from Historical Insurgencies that Have Been Resolved through Negotiations, <www.rand.org/content/dam/rand/pubs/research_reports/RR40o/RR469/RAND_ RR469.pdf>, accessed 31 October 2018.

117 Ivan Márquez, "Para los guerrilleros cero cárcel": Iván Márquez, <www.semana.com/ nacion/articulo/ivan-marquez-dice-que-guerrilleros-de-las-farc-no-pueden-ir-la-carcel/ 418869-3>, accessed 31 October 2018; Zeuxis Pausivas, Kofi Annan se equivoca, no vamos a pagar ni un día de cárcel: FARC, <www.semana.com/nacion/articulo/farc-dicen-que -no-pagaran-carcel-en-respuesta-declaraciones-de-kofi-annan/419700-3>, accessed $3^{1}$ October 2018.

118 Government of Colombia and FARC-EP, supra note 99.
} 
Given the past crimes, and the momentum of peace negotiations and the transitional context steered towards broader political and societal transformation, the Colombian punishment in transition needs to be viewed holistically and evaluated accordingly. The following section, based on the Colombian experience, proposes a list of contextual factors to be taken into consideration for such a holistic evaluation of punishment in negotiated transitions.

\section{5} Contextual Factors Shaping Punishment in Negotiated Transitions

The Colombian case reveals how the particular circumstances of peace negotiations can shape and influence the design of penal measures even for the most serious crimes. It shows that there are factors, beyond the crime and the perpetrator, that shape the design, type and modality of criminal punishment in such transitional contexts. This section briefly outlines general, theoretical considerations on possible contextual factors that impact upon how punishment is negotiated and designed in peace agreements. Each peace negotiation involves a conflict. In peace negotiations the resolution of armed confrontation is dependent on a compromise between adversaries, which would not have cooperated otherwise. ${ }^{119}$ Compromise is at the core of a peace agreement and punishment, when part of a peace accord, does not escape this dynamic. A peace negotiation entails a situation in which conflicting parties face dilemmatic choices. While each party would probably start the negotiation by pursuing its own interests, reaching a final agreement is dependent on the actions of all parties to the negotiation. For this to happen, parties should consider themselves agreeing on a 'win-win solution', which is not only acceptable to them, ${ }^{120}$ but with which they consider themselves better off. ${ }^{121}$ Reaching this common ground implies, however, yielding on issues that might have been considered as essential by either of the parties. Examples include political

119 Alpaslan Ozerdem and SungYong Lee, International Peacebuilding: An Introduction (Routledge, London, 2016).

120 Ibid; Brian Martin, 'The Selective Usefulness of Game Theory', 8 Social Studies of Science (1978), p. 89; Philip Straffin, Game Theory and Strategy (New Mathematical Library, Washington, DC, 2002).

121 Joseph Eaton and David Eaton, Negotiation Strategies in International Disputes, International Project on Violence and Conflicts Caused by Environmental Degradation and Peaceful Conflict Resolution, <www.css.ethz.ch/content/dam/ethz/special-interest/gess/ cis/center-for-securities-studies/pdfs/Environmental_Crisis_1995.pdf $>$, accessed ${ }_{31}$ October 2018 . 
power-sharing, as in the case of South Africa ${ }^{122}$ or issues related to sovereignty, as it happened in Northern Ireland. ${ }^{123}$

In this regard the issue of accountability for past criminality, in which negotiators might have been directly or indirectly involved, is often fundamental. The parties will certainly have some interest in either achieving some degree of impunity (lack of punishment) or accountability (traditional criminal justice and severe sanctions). For instance, an insurgent group negotiating with a state will probably seek full impunity and amnesties. From their viewpoint, negotiating would arguably be useless if it leads to the same outcome as if they had been defeated. ${ }^{124}$ On the other hand, the government, with the mandate and formal authority to punish, might demand harsh sanctions, as ordinarily established in criminal law frameworks, in particular if it believes that its agents will not be, for whatever reason, included in the accountability mechanism. In fact, harsher punishment may enhance the formal authority and legitimacy of the government. ${ }^{125}$ Furthermore, in the context of peace negotiations, punishment as one piece of the negotiated puzzle is intimately interrelated to various (non-punitive) considerations being on the negotiating table.

Accordingly, decisions on punishment, and the extent to which parties to the negotiation are willing to agree or yield on those matters, are contingent on, at least, two sets of factors. First, there are considerations intimately related to the accountability issues and crimes being punished, such as (i) other transitional justice issues under negotiation (beyond the punishment of perpetrators); (ii) interests of victims of crimes and other justice stakeholders (such as potential perpetrators or victims' focused non-governmental organisations); and (iii) international obligations relating to accountability for international crimes and gross human rights violations, by which States are often bound. The second set of considerations relates to broader issues that are often considered important in shaping the outcomes of peace negotiations in general. Consequently, these factors also influence punishment as one of the negotiated items. These include (iv) control over (material and nonmaterial) sources of power (leverage) of each negotiating party; (v) other competing negotiation

122 Mark A. Young, 'Playing Red and Playing Blue. The 1990-94 Negotiation Miracle in South Africa,' 12(2) International Negotiation (2007) 295-310.

123 Steven Brams and Jeffrey M. Togman, 'Agreement through Threats: The Northern Ireland Case', in Fioravante Patrone, Ignacio Garcia Jurado and Stef Tijs (eds.), Game Practice, Contributions from Applied Game Theory (Springer, New York, 200o) pp. 35-52.

124 Michael Scharf, 'The Amnesty Exception to the Jurisdiction of the International Criminal Court', 32(3) Cornell International Law Journal (1999) 508.

125 Keally McBride, Punishment and Political Order (University of Michigan Press, Ann Arbor, 2007) p. 20. 
interests, meaning broader issues under negotiations not directly related to issues of transitional justice; (vi) public opinion and public support of the agreement; and finally (vii) the broader socio-cultural and historical context, in which the peace agreement is negotiated. Each of these contextual factors is briefly explained below.

\subsection{Other Transitional Justice Issues under Negotiation}

Punishment is often negotiated as part of a transitional justice 'package' and in tandem with other mechanisms adopted to address mass atrocity crimes, such as different ways of truth finding, accountability measures, reparations, guarantees of non-repetition, such as institutional reforms, and measures to promote reconciliation. ${ }^{126}$ In such cases, the modality, type and severity of the negotiated sanctions will also depend on how criminal accountability competes with, or relates to other transitional justice interests pursued by the State, by the community or the victims. It may be the case that popular demands, which the State is amenable to, are more focused on truth than punishment and this may shift the balance more towards the creation of a truth commission with wider powers instead of a harsh punitive scheme. In this sense, the severity of punishment might be conditional upon other elements of the judicial and non-judicial transitional justice arrangements and how different transitional justice needs and demands are formulated and negotiated in its totality.

\subsection{Victims' and Other Justice Stakeholders' Needs and Demands}

The pressure of external groups that might be directly or indirectly affected by the final agreement are arguably also instrumental to parties' decision on the extent to which they are willing to yield on prosecutions and sanctions. For instance, victims of conflict-related crimes or (national or international) civil society organisations would probably pressure for accountability or harsher sanctions. They might have a strong position within society, and thus in public opinion. ${ }^{127}$ Additional third parties' interest may include those, who provided financial means or political support for past violence and might be prosecuted as consequence of the accord. These third parties would probably pressure for lack of criminal accountability. The extent to which they succeed might

\footnotetext{
126 Stephan Parmentier, 'Global Justice in the Aftermath of Mass Violence. The Role of the International Criminal Court in Dealing with Political Crimes', 41(1-2) International Annals of Criminology (2003) 203-224.

127 Cf. Kathryn Sikkink, The Justice Cascade. How Human Rights Prosecutions Are Changing World Politics (W.W. Norton \& Company, New York, 2011).
} 
depend on their position within the financial or political system of the country and the political leverage they possess.

\subsection{International Legal Framework}

The extent to which interests regarding accountability and punishment during a peace negotiation are contradictory or overlapping depends on the motivations and aims of each negotiating party. Nevertheless, even if all parties pursue impunity, there is a factor that makes it costly for them to simply agree on avoiding prosecutions and sanctions. Various international legal instruments set forth the obligation for States to prosecute and punish grave human rights violations and international crimes. ${ }^{128} \mathrm{~A}$ breach of this obligation may cause, for instance, the judicial intervention of an international tribunal, such as the International Criminal Court. Nevertheless, these international legal obligations are usually not specific when it comes to penal distribution at the domestic level. Arguably, existing international law provides States with leeway with regards to how to comply with the duty to punish. ${ }^{129}$ This margin of appreciation allows the parties to achieve a punitive 'win-win solution', which brings together their (contradictory) interests while trying to comply with international obligations. In consequence, if an agreement is reached, the means of accountability and the severity and modalities of punishment will be heavily influenced by the political negotiation, while being conditioned by the (international) legal framework. In practice, this cooperative compromise can be materialised through 'creative' modalities of punishment that might not be $e x$ ante regarded in breach of international legal standards.

\subsection{Control over (Material and Nonmaterial) Sources of Power- Leverage of Each Negotiating Party}

Parties to a peace negotiation might have control over different (material and nonmaterial) sources of power, which provide them with different levels of leverage regarding items on the negotiating table, including accountability and punishment for past crimes. Some of these power sources include, for instance, control of armed forces, territorial control, control of natural resources

128 Priscilla Hayner, 'Negotiating Justice - The Challenge of Addressing Past Human Rights Violations', in John Darby and Roger McGinty (eds.), Contemporary Peacemaking: Conflict. Peace Processes and Post War Reconstruction, second edition (Palgrave MacMillan, New York, 2008) pp. 328-338.

129 Claudia Josi, 'Accountability in the Colombian Peace Agreement: Are the Proposed Sanctions Contrary to Colombia's International Obligations', 46 Southwestern Law Review (2017) 401-422. 
or wealth (state assets, commodity exports, predation on local population, theft of humanitarian aid, etc.), popular support or fear, control of media, endorsement by spiritual leaders, external diplomatic or political support. ${ }^{130} \mathrm{Par}-$ ties to the negotiation might also be well informed or misinformed about their relative strength. In any case, their balance of power, and the probability of a military victory or defeat in the absence of negotiations, may move parties to accept or reject specific forms of punishment. For instance, a weak military position could make a rebel group willing to accept moderately severe sanctions for its members, such as reduced prison terms. Conversely, a strong military position could offer a necessary leverage to eliminate imprisonment. Similarly, a military weak state could make the government willing to approve general amnesties for rebels, which would have not been considered in the likelihood of a military victory.

\subsection{Other Competing Negotiation Interests}

A peace negotiation generally concerns different issues which have to be considered as part of an overall bargaining process, even if negotiated throughout different stages. The manipulation of multiple issues becomes most important near the end of a peace negotiation when the parties are searching for ways to bridge the remaining gaps. ${ }^{131}$ At this stage additional concessions might be made in order to reach a complete peace 'package'. Examples of negotiation items, different from criminal accountability and other transitional justice issues, might include political participation, territorial control, public policies on legal and illegal economies, land redistribution and even narratives on the causes of and factors fuelling violence. The negotiating parties might attach different importance to other items under negotiation, thereby affecting their bargaining positions. For instance, adversaries might have varying ideas and multiple disagreements about 'what the conflict is about' and consequently 'different prescriptions for its resolution'. ${ }^{132}$ According to Bell,, ${ }^{133}$ any effort to resolve the conflict during peace negotiations involves an attempt to

130 Chester A. Crocker, Fen Osler Hampson, and Pamela Aall (eds.), Taming Intractable Conflicts: Mediation in the Hardest Cases (United States Institute of Peace, Washington, DC, 2004) pp. 94-95; David R. Smock and Amy L. Smith, Managing a Mediation Process, Peacemaker's Toolkit (United States Institute of Peace, Washington, DC, 2008).

131 Paul R. Pillar, Negotiating Peace. War Termination as a Bargaining Process (Princeton University Press, Guildford, 1983).

132 Christine Bell, 'Negotiating Human Rights', in Darby and McGinty (eds.), supra note 128, p. 213 .

133 Ibid. 
'meta-bargain', i.e. to bargain not only about the concrete outcomes but also over the nature of the conflict, which necessarily involves ways how to resolve it. In this sense, the characterisation of past violence, its purposes and justifications, and how to deal with it in the aftermath of the conflict are part and parcel of this fundamental meta-bargain. This point might be crucial in cases in which the violence was for example considered instrumental by rebels to achieve other objectives such as greater political representation, social justice or territorial control. Punishment may then be counterbalanced by other concessions related to these other, broader interests negotiated as part of the comprehensive accord. In practice, a rebel group may agree to limited prison terms if in exchange it receives other benefits such as political participation or long-term social benefits during the reintegration process. Furthermore, a government may be agreeable to less severe punitive schemes, if the rebel group relinquishes or diminishes its expectations on political participation, or accepts other conditions set out by the government, such as delivering information over illicit trade or organised crime.

\subsection{Public Opinion and Public Support}

Salience and relevance of public opinion regarding the conflict resolution and outcomes of a peace agreement should also not be disregarded. In transitional contexts, punishment for past mass atrocity crimes and justice related issues are often subject to heated, public, emotionally and politically charged, contested discussions. Depending on the sensitivity of negotiating parties to public opinion and the structure of such public opinion, ${ }^{134}$ the negotiating parties might favour a punishment design that will make them politically better off in the future. While compromises in a peace agreement might be a matter of national controversy, public opinion might favour either prosecutions and sanctions that condemn past violence, or conversely (conditional) amnesties and lighter sanctions that enable a ceasefire as soon as possible. A party to the negotiations might opt for the option favouring the strongest public opinion. Such a position would promise future political support and possibly public credibility.

134 For a similar argument in case of inter-state peace negotiations cf. Ben D. Mor, 'Peace Initiatives and Public Opinion: The Domestic Context of Conflict Resolution', 34(2) Journal of Peace Research (1997) 197-215; Peter F. Trumbore, 'Public Opinion as a Domestic Constraint in International Negotiations: Two-Level Games in the Anglo-Irish Peace Process', $42(3)$ International Studies Quarterly (1998) 545-565. 


\subsection{Broader Socio-Cultural and Historical Context}

Peace negotiations are, essentially, the management of human relations involving individuals, groups or nations. ${ }^{135}$ Normally, societies are structured around fundamental values and norms developed through history and culture. ${ }^{136}$ These largely depend on 'the culture and its normative code, and beliefs that characterise national, ethnic or other groups and orient their behavior.'137 Since peace negotiations look to not only resolve a conflict but to do so in a mutually satisfactory manner, these fundamental values - such as justice or general understandings of what is right and wrong - are also addressed and discussed. These values are in practice more relative than universal and thus again context-dependent. For instance, in practice, ideas on how 'justice' can be achieved amidst a peace negotiation might drastically vary if parties belong to a tribal community or to a 'Western-like' highly institutionalised society. In the first scenario, ideas on what is justice and how to achieve it could for example include traditional dispute resolution mechanisms based on indigenous traditions and practices. In contrast, in the second case, proposals on how to achieve justice would most probably encompass solutions based on Western liberal ideas of individual criminal accountability and retributive punishment of individuals, for example.

This categorisation of possible contextual factors offers a first, explorative list of considerations relevant for understanding punishment in negotiated transitions. Arguably these considerations are not exhaustive and in different cases additional factors might appear. It is also important to realise that the different categories are at times overlapping (such as the way how transitional justice issues are resolved relates to the broader socio-cultural and historical context), and consequently are in practice mutually dependent, interact and influence each other. None of them, on their own, can be seen as determinative of the outcome and the particular modality of punishment in transition designed within peace negotiations. The relative importance of each, again, depends on the particular circumstances of each case. These theoretical considerations can offer a basic checklist for future sociological analysis of how

135 Francis M. Deng, The Sudd Institute, Negotiations in a Cultural Context. The Dialogue Brief, $<$ www.google.com/url?sa=t\&rct=j\&q=\&esrc=s\&source=web\&cd=1\&ved=2ahUKEwjorb7

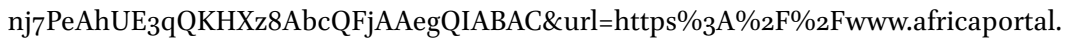
org\%2Fdocuments\%2F17850\%2F59bfc628d4eob_NegotiationsInACulturalContext_Summary.pdf\&usg=AOvVaw17pQKODiRFirPi_vM_PyEo >, accessed 1 November 2018, p. 2.

136 Ibid., p. 3 .

137 Ibid. 
penal policies can be shaped by wider historical, social and political contexts, the particular dynamics of the crimes and the transitional moment of peace negotiations. It should, however, also be emphasised that each case of conflict and its resolution via peace negotiations is unique, and reflects unique conflict histories, contemporary circumstances and different ideas about the future of the transitioning society.

\section{Conclusion}

Societies facing political transitions deal with past political, collective and widespread criminality, which commonly amount to international crimes and grave human rights violations. This, in and of itself, is not an easy task. In addition, in such transitional contexts, processes of creating or consolidating political power structures run parallel. These complex processes, while probably being orchestrated and ran by power elites, involve society at large. Values such as peace, democracy, reconciliation or the rule of law are not only being publicly discussed and contested, but also materialise in public policies, including punishment. In transitional settings, responding to atrocity crimes through criminal punishment is a complex matter. It takes part in a chaotic reality superseding the ordinary challenges societies are used to dealing with in 'normal' times. The decision on whether to forgive and forget or to severely punish past crimes is dependent on several factors, such as the dynamics of the violence or the way by which it ends, and society is transformed. Punishment in transition operates in such volatile contexts.

The case of Colombia is not only the most recent, but also one of the most relevant examples of how punishment is moulded and shaped to accommodate complex realities and the societal necessities of a negotiated political transition. This article offered a detailed description of Colombian punishment in transition. In Colombia, punishment is part of a 'win-win solution' reached by enemies at war, which, in turn, was integrated and intimately related to the peace bargaining process pursuing broader goals of social transformation. Colombian punishment in transition is a new development, which raises a myriad of ethical, legal, political and pragmatic questions. Drawing on the Colombian experience, this article theorised on characteristics of punishment in negotiated transitions, when designed and implemented in contexts of peace agreements.

Over the past 35 years, armed conflicts have predominantly ended with peace negotiations. In 2016, according to the Uppsala Conflict Data Program, 
there were still, at least, 49 active armed confrontations ongoing in the world. ${ }^{138}$ Only in 2016, fatalities worldwide, directly linked to armed conflicts, amounted to $102,000 .{ }^{139}$ Sixty-one out of seventy-seven verified peace agreements concluded between 1980 and 2006 contained either a general reference to principles of human rights or a specific justice mechanism to address past mass atrocity crimes. ${ }^{140}$ Questions of conflict resolution and criminal accountability for past atrocities are intrinsically interrelated, and in the current era of accountability for mass human rights violations and the International Criminal Court, the dilemma of punishment in peace negotiations will certainly remain relevant across different countries and societies. The list of contextual factors proposed in this article to understand and evaluate the design, type and severity of punishment negotiated to deal with mass atrocity is derived drawing heavily on the Colombian case, while taking into account broader literature regarding peace negotiations and their outcomes. There is hardly any literature, theoretical or empirical, regarding the design and evaluation of punishment in negotiated transitions. Future (comparative) research should further nuance, develop and test the proposed contextual factors, looking at other instances of peace negotiations and accountability measures.

138 Margareta Sollenberg and Eric Melander, 'Armed Conflicts and Peace Processes, Patterns of Organized Violence, 2007-2016', in SIPRI Yearbook 2017 (Oxford University Press, Oxford, 2017).

139 Kendra Dupuy, Scott Gates, Havard Mokleiv Nygard, Ida Rudolfsen, Siri Aas Rustad, Hayard Strand and Henrik Urdal, Trends in Armed Conflict, 1946-2016 (PRIO, Oslo, 2017) p. 1.

140 Leslie Vinjamuri L and Aaron P. Boesenecker, Accountability and Peace Agreements. Mapping Trends from 1980 to 2006, <https://www.files.ethz.ch/isn/39727/0907_Accountabilityreport.pdf $>$, accessed 1 November 2018, p. 9 . 